\title{
Effect of Non-Financial Factors on Business \\ Performance of Women Entrepreneurs in Service Industry in Kenya: A Case of KISSI County
}

\author{
Pamela Nyanchama Mochache, MSc (Entrepreneurship) \\ Department of Entrepreneurship and Procurement \\ Jomo Kenyatta University of Agriculture and Technology, Kenya \\ Email: wilfredonyancha2002@yahoo.com \\ Dr. Florence Memba, PhD \\ College of Human Resource Development \\ Jomo Kenyatta University of Agriculture and Technology, Kenya
}

Doi:10.5296/ jebi.v2i1.6857 URL: http://dx.doi.org/10.5296/ jebi.v2i1.6857

\begin{abstract}
The important role that entrepreneurship played to combat unemployment, wealth creation and the alleviation of poverty was not underestimated, especially in regions with growing unemployment rates. Women entrepreneurs could contribute significantly to economic development in Kenya, but their contribution had been documented to be wanting. Although it was challenging for both men and women to start and sustain a successful business, women faced unique challenges in their business ventures. The objective of this study was to assess non-financial factors influencing the business performance of women entrepreneurs for women-owned enterprises in Kisii County. The study was based on the factors affecting the business performance of women entrepreneurs operating within Kisii County involved in micro and small businesses in the service industry. The study attempted to determine the constraints of women entrepreneurs in the service industry by identifying constraints limiting their business performance.
\end{abstract}

Keywords: Attributes of women entrepreneurs, education, attitude and experience 


\section{Introduction}

The characteristics or attributes of women entrepreneurs were regarded as the pull factors in entrepreneurial activity (Kuzilwa, 2005). These included factors such as age and education, type of employment, type of industry, type of company, financial background and work experience (Harrison \& Mason, 2007). They were regarded as the human capital or internal factors to be contributed by the entrepreneur in exploiting entrepreneurial opportunity for business performance. The ones most critical to women entrepreneurs which were discussed below were education, attitude and experience. Namusonge (1995) stated that business success depended critically on the personal attributes of the entrepreneur such as self-confidence, creativity, innovation and the drive to take risks. Further, Shelton (2006) observed that the know-how and therefore performance of the enterprise was a result of the personal contacts and networks of the entrepreneur. Thus, the performance of an entrepreneur could be attributed to his/her characteristics. The objective of this study was to establish whether there is a significant relationship between demographic characteristics (such as education, type of employment, type of industry, type of company, financial background and work experience) and business performance of women owned MSEs in the service industry in Kenya.

\section{Education}

Education was one of the characteristics of women entrepreneurs that can affected their business performance, and literature supported that education and managerial experience may contribute to women's business growth but certainly had positive impact on entrepreneurial performance (Gatewood, Carter, Gartner, \& Shaver, 2004). They also stated that human capital is not only the result of formal education and training but also included experience and practical learning derived from previous paid employment or managerial position, and it was a vital condition for technological innovation (Gatewood, Carter, Gartner, \& Shaver, 2004).

McCormick (2001) posited that on average women entrepreneurs were less educated than their male counterparts and twice as likely as men to be illiterate. The major reasons for this difference were institutional in nature. Marriage institutions discouraged investment in women's education and the division of labour assigned a greater share of household responsibility to girls. Because they had lower educational attainment, they were also less likely to benefit from management and technical training programmes.

According to McKay (2001), individuals with a high level of education were more likely to engage in entrepreneurship. An individual with more work experience, a higher level of education, more knowledge of the market and business practice was more likely to be able to identify an opportunity for starting a new business. On the other hand, it was expected that people with a low level of education had more difficulties finding a paid job, and therefore see no other possibility than to engage in entrepreneurship. Hence, high educated people were more likely to pursue opportunity-based ventures, while less educated entrepreneurs were more involved in necessity entrepreneurship. 
More specific to women studies done by Kavitha, et al (2008), women were found to be more mature in terms of age, level of education and equipped with work experience in comparison to non-entrepreneurs. In USA for example, most women entrepreneurs had tertiary education followed by high school education (Gatewood, Carter, Gartner, \& Shaver, 2004).

\section{Attitude}

Attitude towards risk-taking was another crucial attribute of entrepreneurs especially women. This was because enterprise involved risk-taking, and risk-averse entrepreneur was less likely to exploit entrepreneurial opportunity (Shane, 2003). Attitude towards risk-taking was entrepreneur's ability and willingness to engage in risky activity (Shane, 2003). Attitude and behavioural intention were positively related and that attitude towards behaviour led to intention which eventually led to actual behaviour (Crisp \& Turner, 2009).

\section{Experience}

Crisp \& Turner (2009) asserted that business experience was one of the vital entrepreneurial characteristics and evidences support the fact that a minimum of two to three years business experience was sufficient to assess an entrepreneur. Other characteristics of women entrepreneurs included: strong desire for independence, innovation, risk-taking, resourcefulness, business skills, knowledge, and networks (Salman, 2009). Further, Salman (2009) asserted that the owner-managers' previous work experience and skills acquired on the job were important factors contributing to business success and growth. Other factors were: knowing the market and understanding the needs of customers, access to capital, assistance from family members, net working with friends, from former school and colleges. Finally, hard work as evidenced by long working hours, contributed to the success of an entrepreneur.

\section{Business Knowledge and Skills}

This was knowledge of top players in the industry, knowledge of product range and market trends. Business skills included technical and managerial skills which could be acquired through training, seminars and workshops. Experience could be acquired through formal education and business knowledge and possession of business skills, previous experience and support of family members were essential for business success in Kenya (Salman, 2009).

The need for achievement and autonomy, risk-taking, control of business and self-efficacy were other vital characteristics of women entrepreneurs (Shane, 2003). Demography, skills and reputation were also essential attributes of women entrepreneurs as single women had less income and less guarantees for loan. Family size also affected women entrepreneurial activity. Despite the fact that women with one or two children were likely to participate in entrepreneurial activity, in Pakistan for example, in order to generate income to support their families (Salman, 2009), it was however discovered that most women with family sizes of more than five people were likely to become entrepreneurs and large family size is common in developing countries (Lakwo, 2007). Again, most women aged between 25-34 years were found in the early- stage entrepreneurship (Allen \& Economy, 2008). 
Ambition, self-confidence and high level of energy had also been recognized as vital entrepreneurial characteristics (Idris \& Mahmood, 2003). Having the right motive of venturing into business had been found to be one of the attributes of women entrepreneurs. The right motive should be the first determinant before entering into business (Shane, 2003). Self-evaluation and intuition were also crucial characteristics (Shane, 2003). However, focusing on education, experience and attitude towards risk-taking as vital individual attributes of women entrepreneurs, we therefore made the following proposition:

The second factor had to do with the opportunity to accumulate savings. Because women had lower levels of education and were segregated into lower paying jobs, they had lower savings with which to start a business. Thirdly, women spend less time in their businesses than men because they were expected to carry out their domestic responsibilities, including housework, food preparation and childcare. This also explained why women were more likely to operate their business from the home. McCormick concluded that gendered patterns of business operations were supported by five institutions - the incorporation of the wife into the husband's family, the division of labour within the household, the division of asset ownership (the tradition that vests ownership of land in males remains strong, even though women could purchase and inherit land), the sharing of household expenditures, and the allocation of educational opportunities (Mitchell, 2004).

\section{Methodology}

This study employed a survey research design. A survey design was preferred for it facilitated the collection of a considerable amount of data quickly, efficiently and accurately (Oso \& Onen, 2005).This research design was preferred because it permitted the collection of data through questionnaires administered to a sample of respondents and that the data collected by this design could be used to suggest reasons for particular relationships between variables and produce models for these relationships (Saunders \& Thornhil, 2007).

A structured questionnaire was self-administered to the women entrepreneurs involved in the start-up and day to day running of these businesses to gather primary quantitative data. A structured questionnaire was preferred because it was the most suitable tool for a cross-sectional survey research and it was the best suited for a study concerned with the collection of views, perceptions and feelings which could not be observed (Oso \& Onen, 2005). Perceptual measures were preferred since data on the majority of the MSEs was not publicly available, making it difficult to check the accuracy of any data reported. The Likert scale was also preferred as it was able to deal with a large number of items and difficulties in eliciting specific information from the respondents (Singh \& Smith, 2006).

The colleceted data was analyzed using descriptive statistics including frequencies, percentages and weighted averages. Descriptive statistics described relevant aspects of the factors influencing the business performance of Women owned MSES in the service industry. Weighted averages were used to rank the Likert scale items. Cross tabulations and Chi-square test were used to test the association between the demographic attibutes,entrepreneurial mind sets and level of access to business development services and business performance. Analyzed data was presented in tables. Statistical software package for social sciences 
(SPSS) was used to generate the required statistics for analysis.

\section{Findings}

\section{Age of Respondents}

The study indicated that $42.9 \%$ of the respondents were between $30-39$ years of age, $37.4 \%$ were between 40-49 years of age as depicted from the Table 1 below. These findings deduce that most of women entrepreneurs in the service industry were of an age category 30-49 which shows that they have been entrepreneurs for long period of time. It was evident from the study that the age of the respondents affected the business performance of women owned MSEs in Kisii County. Most women entrepreneurs were at the youthful age of $30-49$ years whereby they could perform their activities aggressively leading to high performance.

\section{Table 1: Age of respondents}

\begin{tabular}{llll}
\hline Age bracket & Frequency & Percentage & $\begin{array}{l}\text { Cumulative } \\
\text { percentage }\end{array}$ \\
Below 19 years & 3 & 1.5 & 1.5 \\
20-29 years & 20 & 10.1 & 11.6 \\
30-39 years & 85 & 42.9 & 54.5 \\
$40-49$ years & 74 & 37.4 & 91.9 \\
$50-59$ years & 15 & 7.6 & 99.5 \\
Above 60 years & 1 & 0.5 & 100.0 \\
Total & $\mathbf{1 9 8}$ & $\mathbf{1 0 0 . 0}$ & $\mathbf{1 0 0 . 0}$ \\
\hline
\end{tabular}

Source: Survey data, 2013

\section{Marital status}

From Table 2, the study indicated that $79.7 \%$ of the respondents were married while $9.6 \%$ were single. From the findings shown below, it was indicated that if women entrepreneurs who were married, had no self employed mother/sister, had low educational background and were not experienced in business, all these could lead to the conclusion that, the personal characteristics of these entrepreneurs could contribute to their low performance in addition to the economic, social, and legal/administrative factors. 
Table 2: Marital status

\begin{tabular}{llll}
\hline Marital status & Frequency & $\begin{array}{l}\text { Percentage } \\
\text { frequency }\end{array}$ & $\begin{array}{l}\text { Cumulative } \\
\text { percentage }\end{array}$ \\
Single & 19 & 9.6 & 9.6 \\
Married & 158 & 79.8 & 89.4 \\
Divorced & 9 & 4.5 & 93.9 \\
Widowed & 12 & 6.1 & 100.0 \\
Total & $\mathbf{1 9 8}$ & $\mathbf{1 0 0 . 0}$ & $\mathbf{1 0 0 . 0}$ \\
\hline
\end{tabular}

Source: Survey data, 2013

\section{Level of education}

The level of education was measured by the number of formal schooling. In Table 3 results revealed that $32.3 \%$ of the respondents had attained a diploma level. Those with a bachelor's degree were $21.2 \%$. This is an indication that most of the women entrepreneurs turn to business when they fail to continue with education to a degree level. The results showed that those that had a bachelor's degree had a good perceived level of business name awareness compared with those women entrepreneurs with only a primary or secondary certificate. These results collaborated with the findings of McKay (2001) who established that individuals with a high level of education were more likely to engage in entrepreneurial activities more successfully than those with low level of education.

Table 3: Level of education

\begin{tabular}{|c|c|c|c|}
\hline Highest level of education & Frequency & Percentage & Cumulative \\
\hline Primary/Secondary & 32 & 16.2 & 16.2 \\
\hline Certificate & 47 & 23.7 & 39.9 \\
\hline Diploma & 64 & 32.3 & 72.2 \\
\hline Bachelor & 42 & 21.2 & 93.4 \\
\hline Master & 13 & 6.6 & 100.0 \\
\hline Total & 198 & 100.0 & 100.0 \\
\hline
\end{tabular}

Source: Survey data, 2013 


\section{Length of operation}

The study as shown in Table 4 indicated that $39.4 \%$ of the women entrepreneurs had operated their business for at least 5 years while $17.2 \%$ had only operated for two years.

Table 4: Length of operation

\begin{tabular}{llll}
\hline $\begin{array}{l}\text { Length of business } \\
\text { operation }\end{array}$ & Frequency & $\begin{array}{l}\text { Percentage } \\
\text { frequency }\end{array}$ & $\begin{array}{l}\text { Cumulative } \\
\text { percentage }\end{array}$ \\
$\begin{array}{l}\text { Below 2 years } \\
\text { 2-5 years }\end{array}$ & 34 & 17.2 & 17.2 \\
6-10 years & 78 & 39.4 & 56.6 \\
Above 10 years & 43 & 21.7 & 78.3 \\
Total & $\mathbf{1 9 8}$ & 21.7 & 100.0 \\
\hline
\end{tabular}

Source: Survey data, 2013

Type of business

As indicated in Table 5, most women entrepreneurs had retail business with $62.1 \%$ and the least number were in dressmaking with $5.1 \%$.

Table 5: Type of business

\begin{tabular}{llll}
\hline Type of business & Frequency & $\begin{array}{l}\text { Percentage } \\
\text { frequency }\end{array}$ & $\begin{array}{l}\text { Cumulative } \\
\text { percentage }\end{array}$ \\
Retail & 123 & 62.1 & 62.1 \\
Salon & 25 & 12.6 & 74.7 \\
Dressmaking & 10 & 5.1 & 79.8 \\
Food/beverages/restaurant & 40 & 20.2 & 100.0 \\
Total & $\mathbf{1 9 8}$ & $\mathbf{1 0 0 . 0}$ & $\mathbf{1 0 0 . 0}$ \\
\hline
\end{tabular}

Source: Survey data, 2013 


\section{Number of employees}

Table 6 indicated that the highest number of employees were self-employed.

Table 6: Number of employees in the business

\begin{tabular}{llll}
\hline $\begin{array}{l}\text { Number of employees } \\
\text { in the business }\end{array}$ & Frequency & $\begin{array}{l}\text { Percentage } \\
\text { frequency }\end{array}$ & $\begin{array}{l}\text { Cumulative } \\
\text { percentage }\end{array}$ \\
Self & 94 & 47.5 & 47.5 \\
Between 2-4 & 57 & 28.8 & 76.3 \\
Between 5-10 & 18 & 9.1 & 85.4 \\
Between 11-25 & 23 & 11.6 & 97.0 \\
Between 26-50 & 6 & 3.0 & 100.0 \\
Total & $\mathbf{1 9 8}$ & $\mathbf{1 0 0 . 0}$ & $\mathbf{1 0 0 . 0}$ \\
\hline
\end{tabular}

Source: Survey data, 2013

\section{Conclusions and recommendations}

The non-financial factors had a remarkable influence on the business performance of women who owned micro and small scale enterprises in the service industry in Kenya. As shown on the Tables 1-6, it was established that education, type of employment, type of industry, type of company, financial background and work experience affected the business performance of women owned MSEs in the service industry in Kenya. The government incentives such as seminars and conferences for women entrepreneurs would greatly help them to improve their business management knowledge and to gain higher business performance. Furthermore, government as well as women organizations should cooperate with matured business in providing guidance to newly established entrepreneurs. Conducting hands-on workshops is also a way of motivating these women entrepreneurs to improve their skills and confidence. Lastly, women entrepreneurs should also be encouraged to take on the government assistance and join the events organized by government or any women organizations. Suggested assistance that can be offered by the government and women organizations include assistance especially during economic downturn, seminars and courses on operation management, business administration, marketing and promotions, usages of ICT, motivations and business planning. This can give them more exposure and knowledge on other factors that could improve their business as well as increase their business performance. Women entrepreneurs in MSEs of the town should share experiences with other entrepreneurs in other 
towns and regions so that they can learn a lot from best practices of those entrepreneurs.

\section{References}

Allen, K., \& Economy, P. (2008). Complete MBA for dummies. New Jersey: Wiley Publishing,Inc.

Crisp, R., \& Turner, R. (2009). Essential Social Psychology. London:SAGE Publication Entrepreneurs. Malaysian Management Review .

Gatewood, E., Carter, N., Gartner, W., \& Shaver, K. (2004). The Career Reasons of Nascent Entrepreneurs. Journal of Business Venturing, 18, 13-39.

Harrison, R., \& Mason, C. (2007). Does gender matter? Women business angels and the supply of entrepreneurial finance. Entrepreneurship Theory and Practice, 31 (3) , 445-472.

Idris, A., \& Mahmood, R. (2003). Bank managers' perceptions of the characteristics of successful entrepreneurs. Malaysian Management Review, 38 (1) .

Kavitha, R., Anantharaman, R., \& Sharmila, J. (2008). Motivational Factors Affecting Entrepreneurial Decision: A comparison between Malaysian Women Entrepreneurs and Women Non-entrepreneurs. Communications of the IBIMA, 2 , 85-89.

Kuzilwa, J. (2005). The role of credit for small business success. A study of the National Entrepreneurship, 14 (2) , 131-161.

Lakwo, A. (2007). Microfinance, rural livelihood, and women's empowerment in Uganda. Uganda: African Studies Center.

McCormick, D. (2001). Research on women in small enterprises in Kenya, paper prepared for the REME Workshop. Nairobi: Institute of Development Studies, University of Nairobi.

McKay, R. (2001). Women Entrepreneurs, Moving Beyond Family and Flexibility. International Journal of Intrepreneurial Behaviour and Research, Vol.7,No.4 , 148-165.

Mitchell, B. (2004). Motives of entrepreneurs: A case study of South Africa. Journal of Entrepreneurship, 13 (1) , 168-183.

Namusonge, G. (1995). Determinants of Growth Oriented Enterprises in Nairobi Area. Juja: Jomo Kenyatta University of Agriculture and Technology.

Oso, W., \& Onen, D. (2005). A General Guide to Writing Research Proposals and Reports. A Handbook for Beginning Researchers, (2nd ed.). Kampala, Uganda: Makerere University Press.

Salman, A. (2009). How to start a business: A guide for women. Pakistan: Center for International Private Enterprise, Institute of National Endowment for Democracy, affiliate of the USA Chamber of Commerce.

Saunders, M., \& Thornhil, L. (2007). Research Methods in Business. UK: McGraw Hill Publishers. 


\section{Macrothink}

Journal of Entrepreneurship and Business Innovation

ISSN 2332-8851

2015, Vol. 2, No. 1

Shane, S. (2003). A General Theory of Entrepreneurship. The Individual-opportunity. Nexus, UK: Edward Elgar.

Shelton, L. (2006). Female Entrepreneurs, Work-Family Conflict and Venture Performance: New Insights into the Work-Family Interface. Journal of Small Business Management, 44(2), 285-297.

Singh, P., \& Smith, A. (2006). An Empirically Validated Quality Management Instrument. 


\section{APPENDIX:}

Relationship between demographic characteristics and business performance of women owned MSE's.

Table I: age of respondent * level of business name awareness

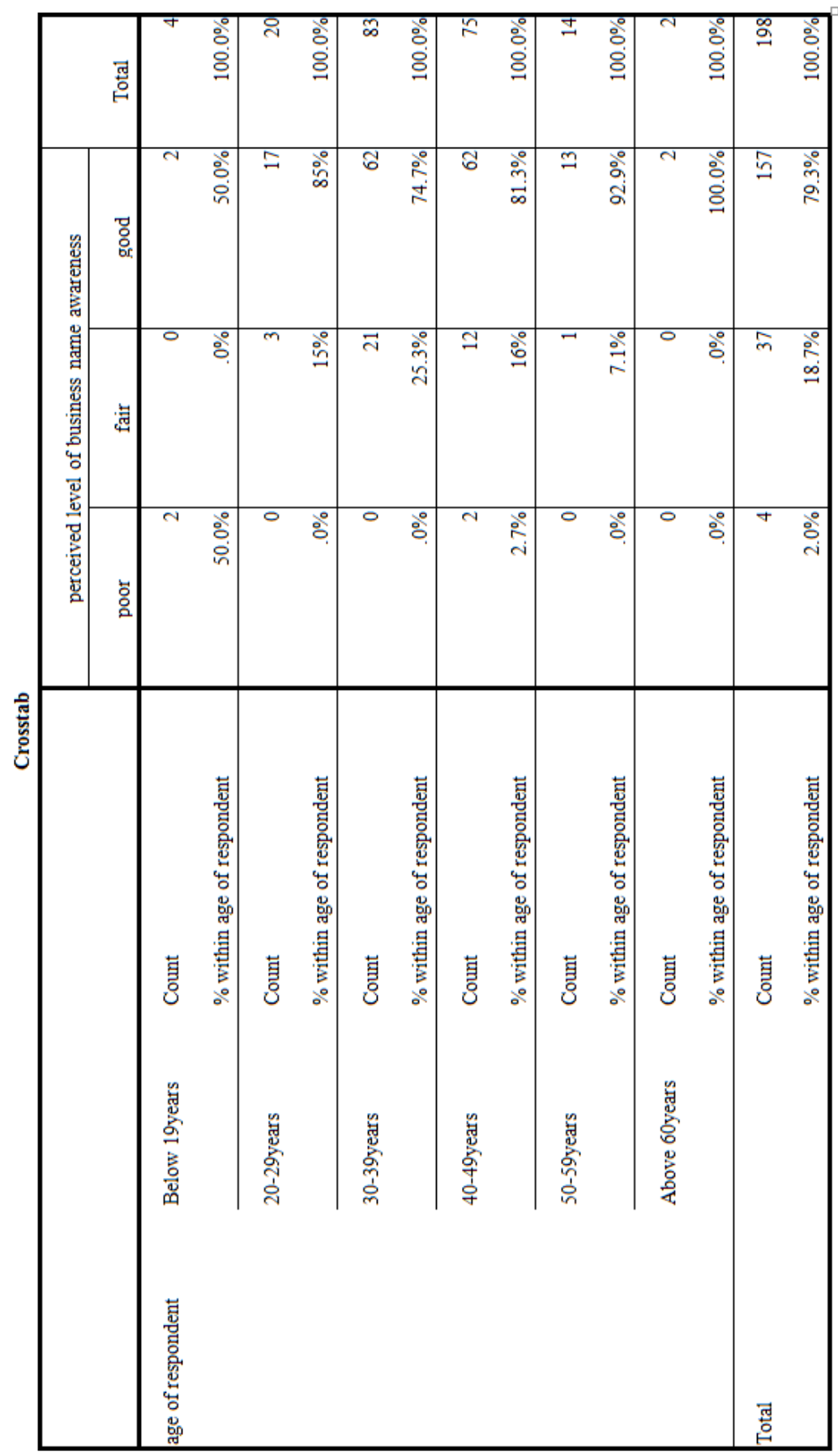


Chi-Square Tests

\begin{tabular}{|l|l|l|l|}
\hline & Value & df & $\begin{array}{l}\text { Asymp. Sig. } \\
(2 \text {-sided })\end{array}$ \\
\hline Pearson Chi-Square & $29.899^{\mathrm{a}}$ & 10 & .001 \\
Likelihood Ratio & 13.564 & 10 & .194 \\
Linear-by-Linear & 1.224 & 1 & .268 \\
Association & 198 & & \\
\hline
\end{tabular}

a. 12 cells $(66.7 \%)$ have expected count less than 5 . The minimum expected count is .02 . 
Table II: age of respondent * level of customer retain 2015, Vol. 2, No. 1

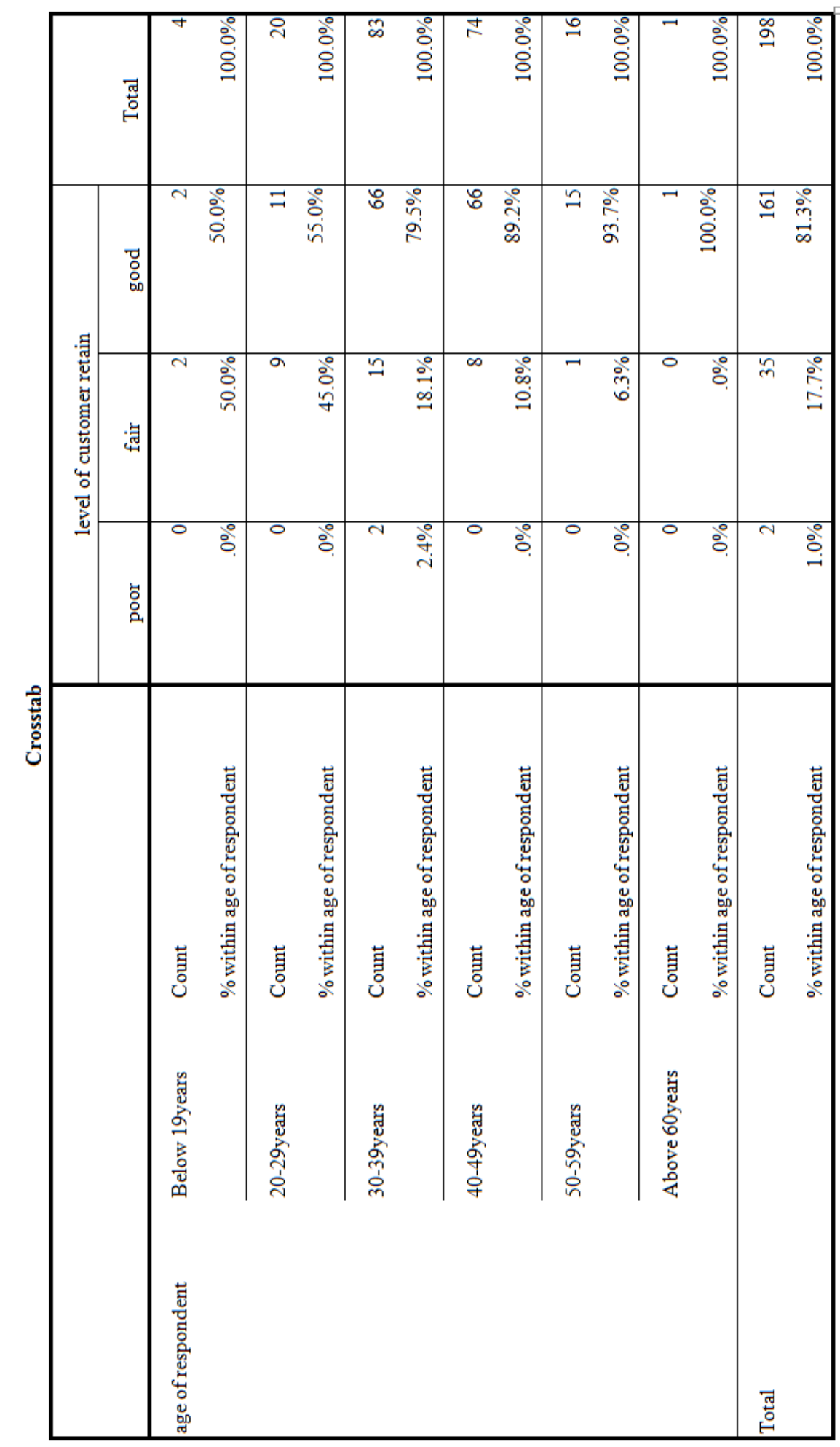




\section{Chi-Square Tests}

\begin{tabular}{|l|l|l|l|}
\hline & Value & df & $\begin{array}{l}\text { Asymp. Sig. } \\
(2 \text {-sided })\end{array}$ \\
\hline Pearson Chi-Square & $20.295^{\mathrm{a}}$ & 15 & .161 \\
Likelihood Ratio & 19.766 & 15 & .181 \\
Linear-by-Linear & 11.101 & 1 & .001 \\
Association & 198 & & \\
\hline
\end{tabular}

a. 15 cells $(62.5 \%)$ have expected count less than 5 . The minimum expected count is .01 . 
Table III: marital status * perceived level of business name awareness

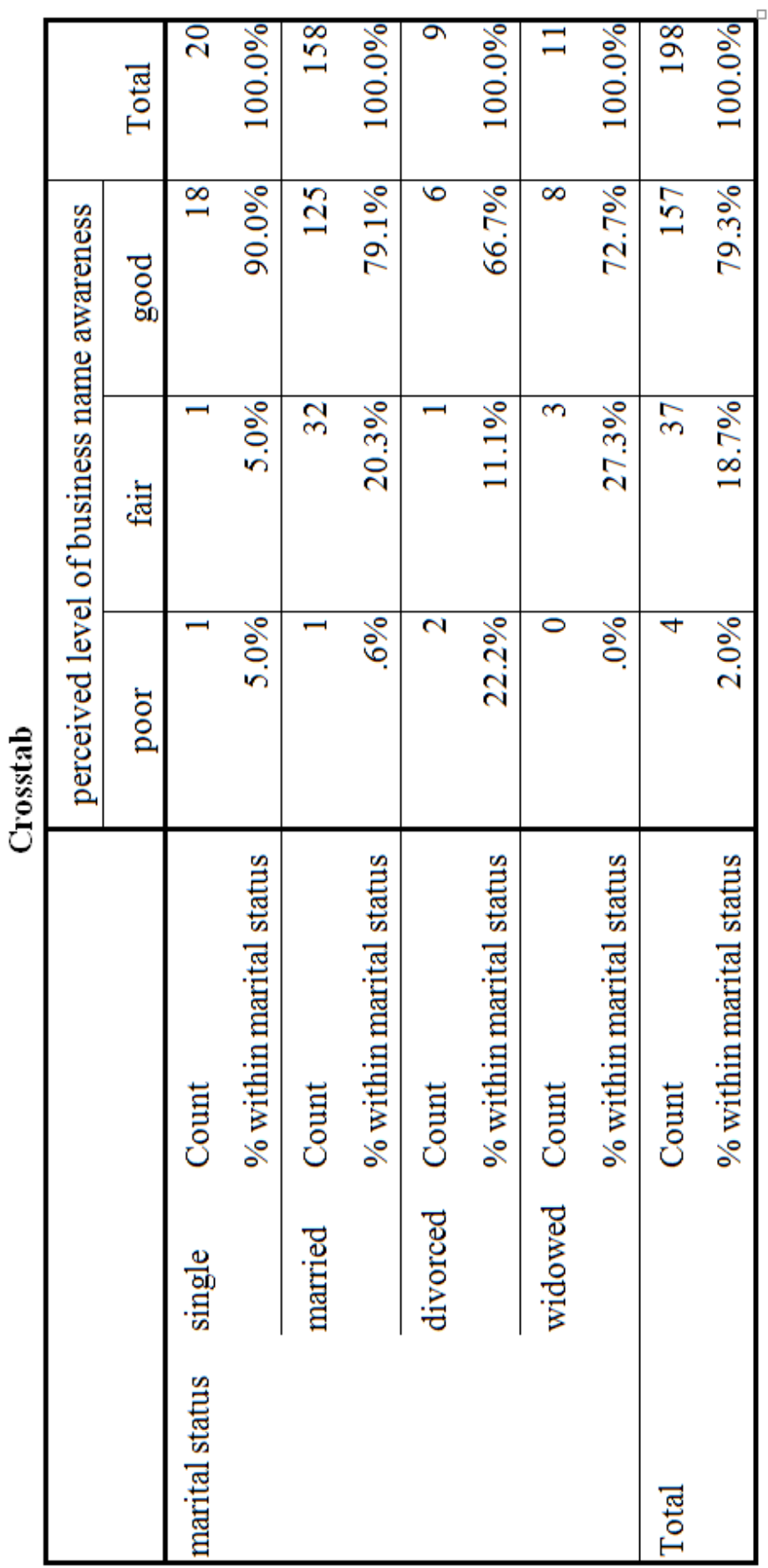




\section{Chi-Square Tests}

\begin{tabular}{|l|l|l|l|}
\hline & Value & df & $\begin{array}{l}\text { Asymp. Sig. } \\
(2 \text {-sided })\end{array}$ \\
\hline Pearson Chi-Square & $9.584^{\mathrm{a}}$ & 6 & .143 \\
Likelihood Ratio & 6.651 & 6 & .354 \\
Ainear-by-Linear & .412 & 1 & .521 \\
Association & 198 & & \\
\hline
\end{tabular}

a. 7 cells $(58.3 \%)$ have expected count less than 5 . The minimum expected count is .14. 
Table IV: highest level of education * perceived level of business name awareness

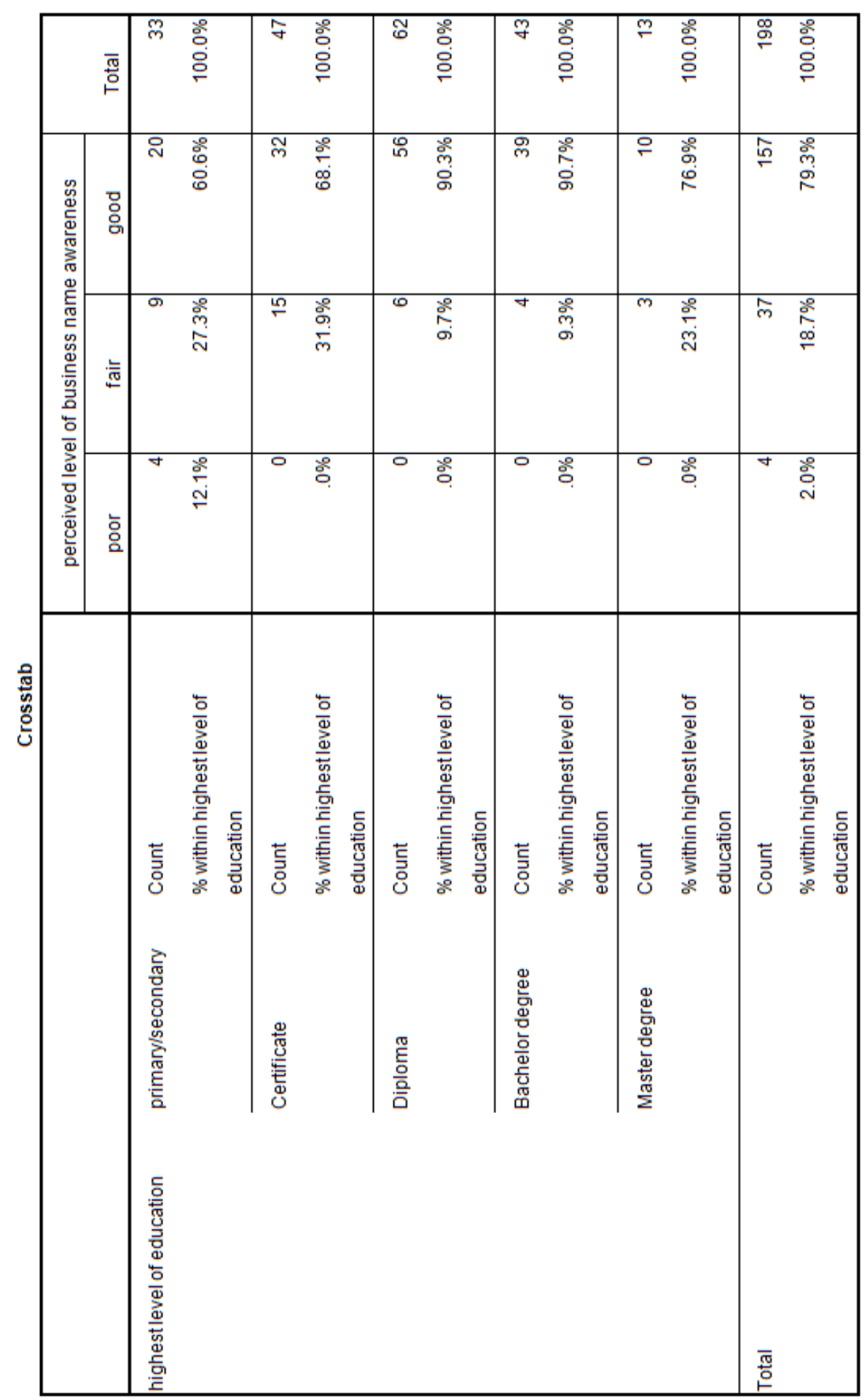




\section{Chi-Square Tests}

\begin{tabular}{|l|l|l|l|}
\hline & Value & $\mathrm{df}$ & $\begin{array}{l}\text { Asymp. Sig. } \\
(2 \text {-sided })\end{array}$ \\
\hline Pearson Chi-Square & $25.567^{\mathrm{a}}$ & 8 & .001 \\
Likelihood Ratio & 21.192 & 8 & .007 \\
Ainear-by-Linear & 10.596 & 1 & .001 \\
Association & 198 & & \\
\hline
\end{tabular}

a. 7 cells $(46.7 \%)$ have expected count less than 5. The minimum expected count is .20 . 
Table V: highest level of education * level of customer retain

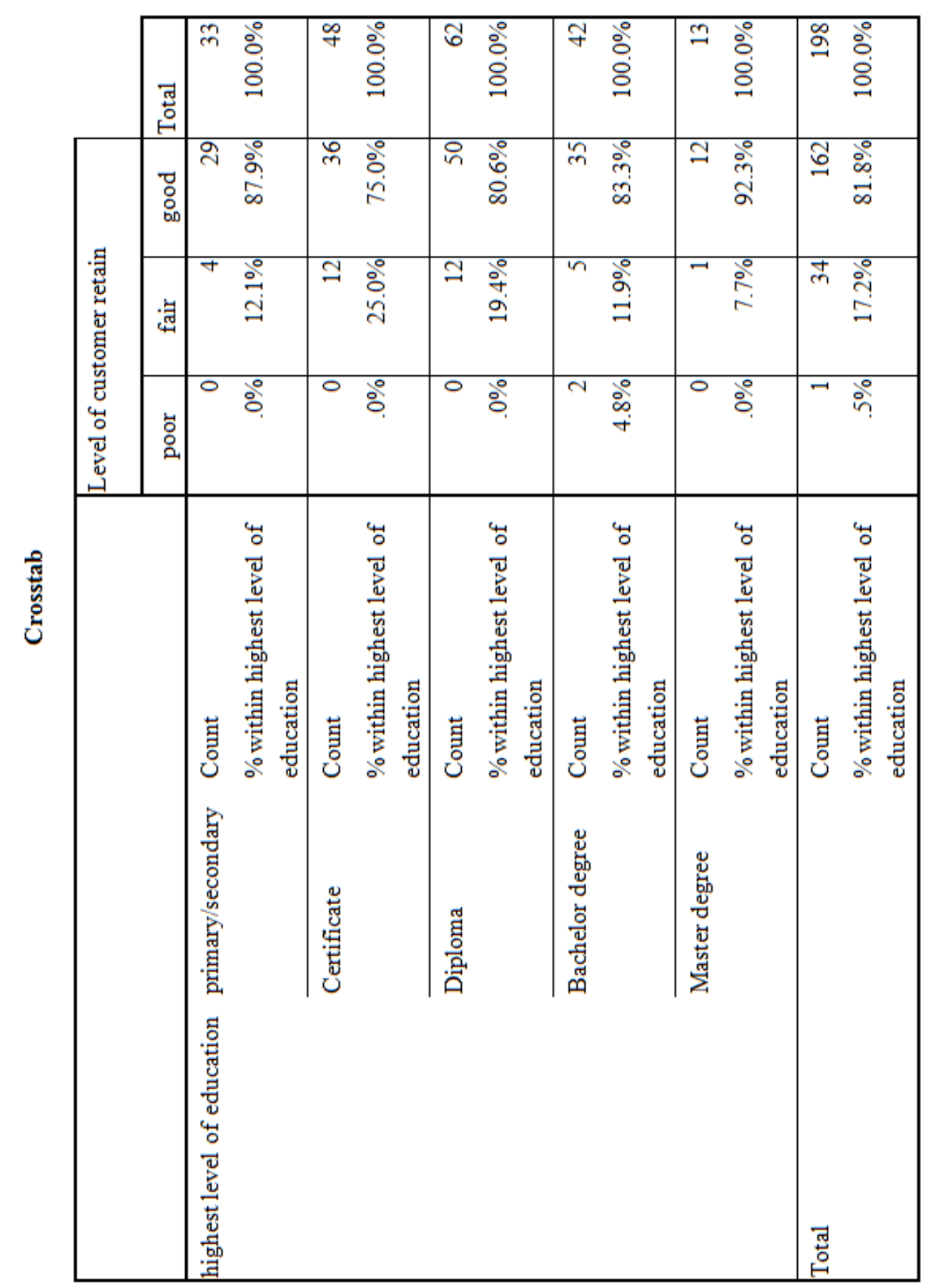




\begin{tabular}{lr} 
Macrothink & Journal of Entrepreneurship and Business Innovation \\
Institute & 2332-8851 \\
IM & 2015, Vol. 2, No. 1 \\
\hline
\end{tabular}

\section{Chi-Square Tests}

\begin{tabular}{|l|l|l|l|}
\hline & Value & $\mathrm{df}$ & $\begin{array}{l}\text { Asymp. Sig. } \\
(2 \text {-sided })\end{array}$ \\
\hline Pearson Chi-Square & $18.987^{\mathrm{a}}$ & 12 & .089 \\
Likelihood Ratio & 18.606 & 12 & .099 \\
Linear-by-Linear & .117 & 1 & .733 \\
Association & 198 & & \\
\hline N of Valid Cases & & & \\
\hline
\end{tabular}

a. 9 cells $(45.0 \%)$ have expected count less than 5. The minimum expected count is .07 . 


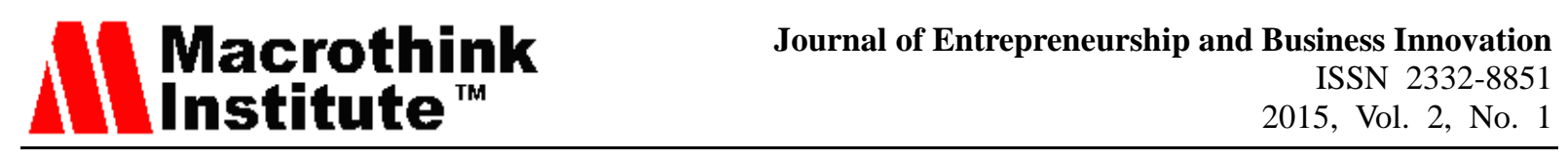

Table VI: length of business operation * perceived level of business name awareness

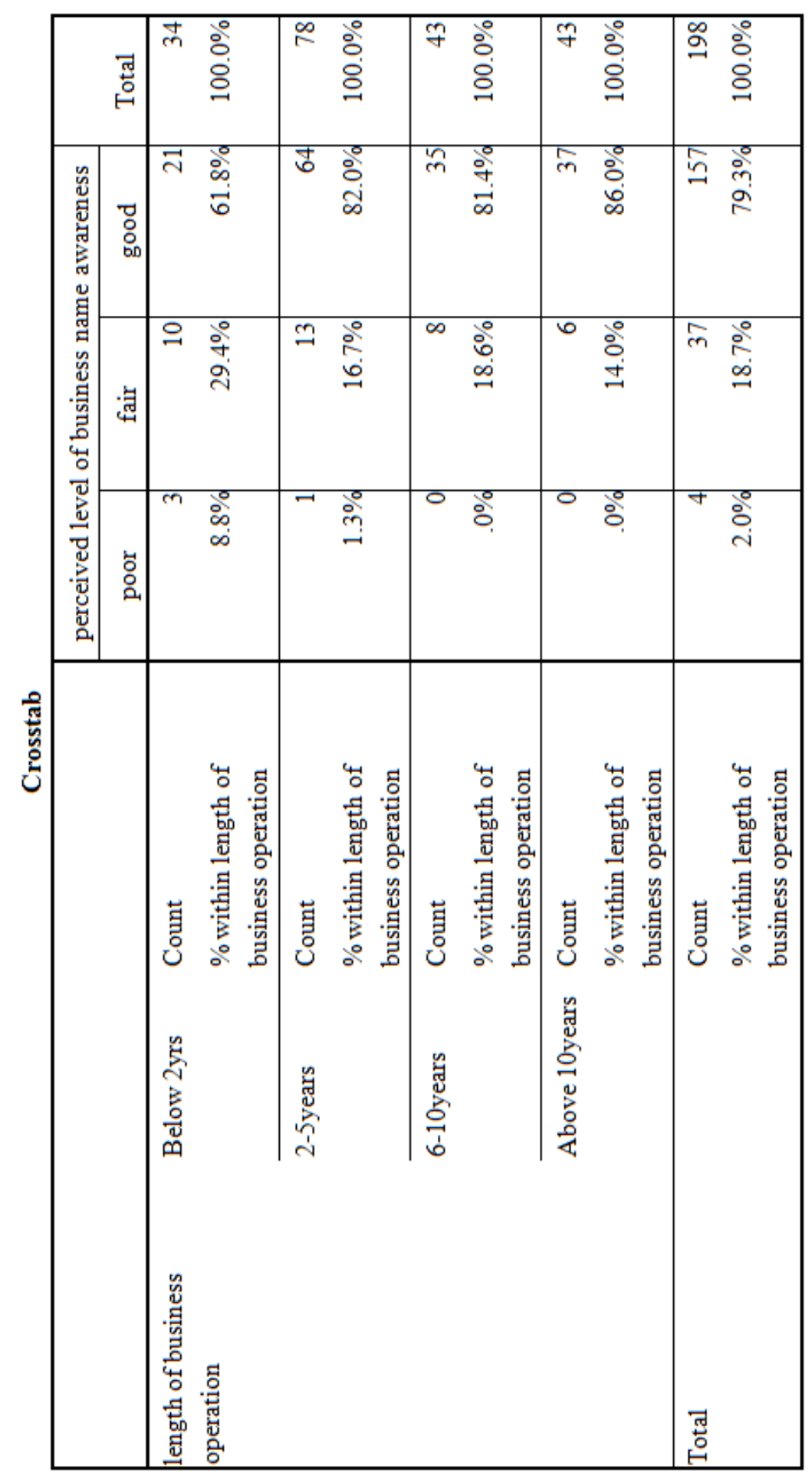




\begin{tabular}{lr} 
Macrothink & Journal of Entrepreneurship and Business Innovation \\
Institute & 2332-8851 \\
IM & 2015, Vol. 2, No. 1 \\
\hline
\end{tabular}

\section{Chi-Square Tests}

\begin{tabular}{|l|l|l|l|}
\hline & Value & $\mathrm{df}$ & $\begin{array}{l}\text { Asymp. Sig. } \\
(2 \text {-sided })\end{array}$ \\
\hline Pearson Chi-Square & $9.392^{\mathrm{a}}$ & 6 & .153 \\
Likelihood Ratio & 8.787 & 6 & .186 \\
Linear-by-Linear & 5.621 & 1 & .018 \\
Association & 198 & & \\
\hline N of Valid Cases & & & \\
\hline
\end{tabular}

a. 5 cells $(41.7 \%)$ have expected count less than 5 . The minimum expected count is .53 . 
Table VII: length of business operation * level of customer retain

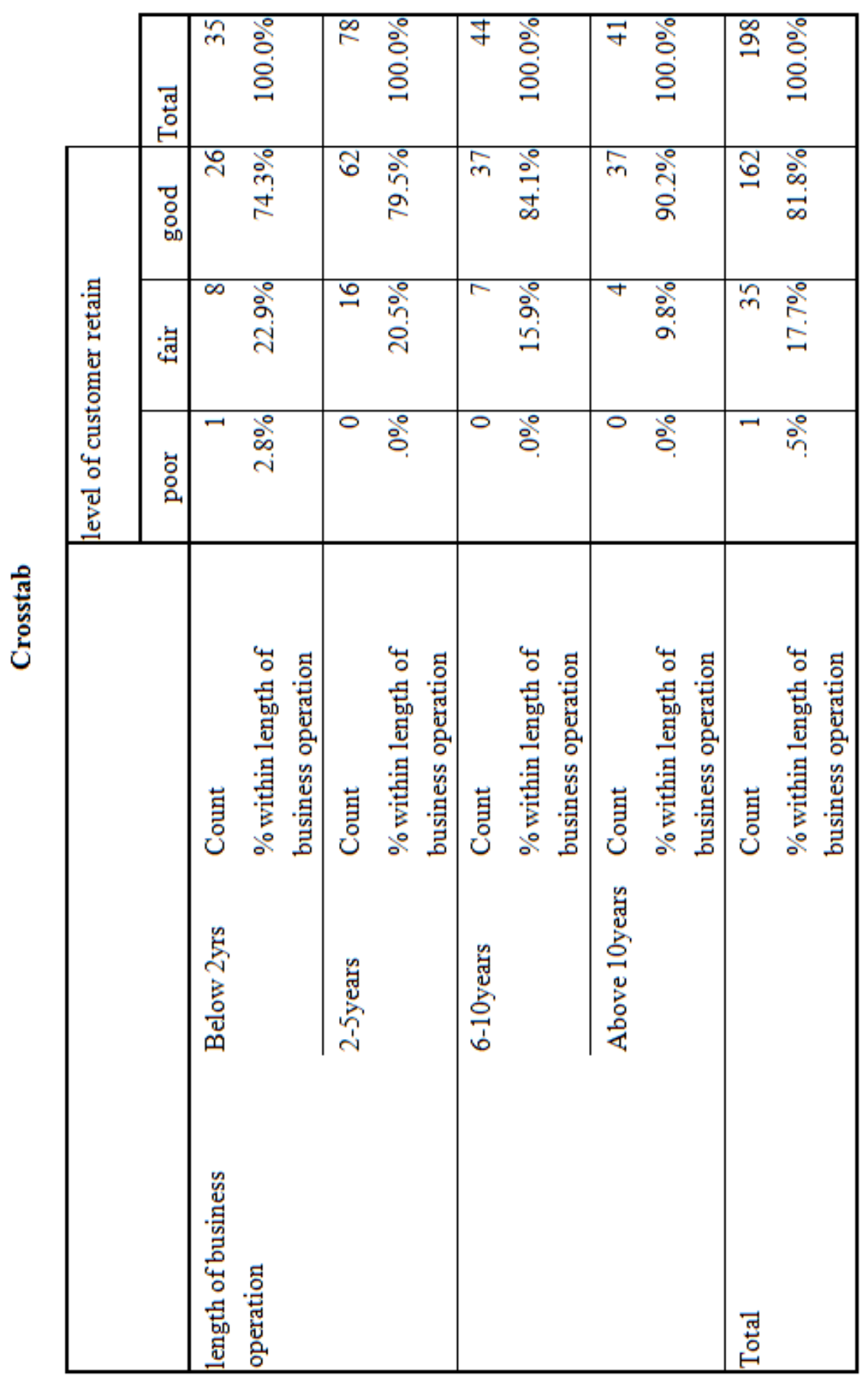




\section{Macrothink

\section{Chi-Square Tests}

\begin{tabular}{|l|l|l|l|}
\hline & Value & $\mathrm{df}$ & $\begin{array}{l}\text { Asymp. Sig. } \\
(2 \text {-sided })\end{array}$ \\
\hline Pearson Chi-Square & $10.984^{\mathrm{a}}$ & 9 & .277 \\
Likelihood Ratio & 9.751 & 9 & .371 \\
Linear-by-Linear & 5.604 & 1 & .018 \\
Association & 198 & & \\
\hline
\end{tabular}

a. 5 cells $(31.3 \%)$ have expected count less than 5 . The minimum expected count is .17 . 
Table VIII: number of employees * perceived level of business name awareness

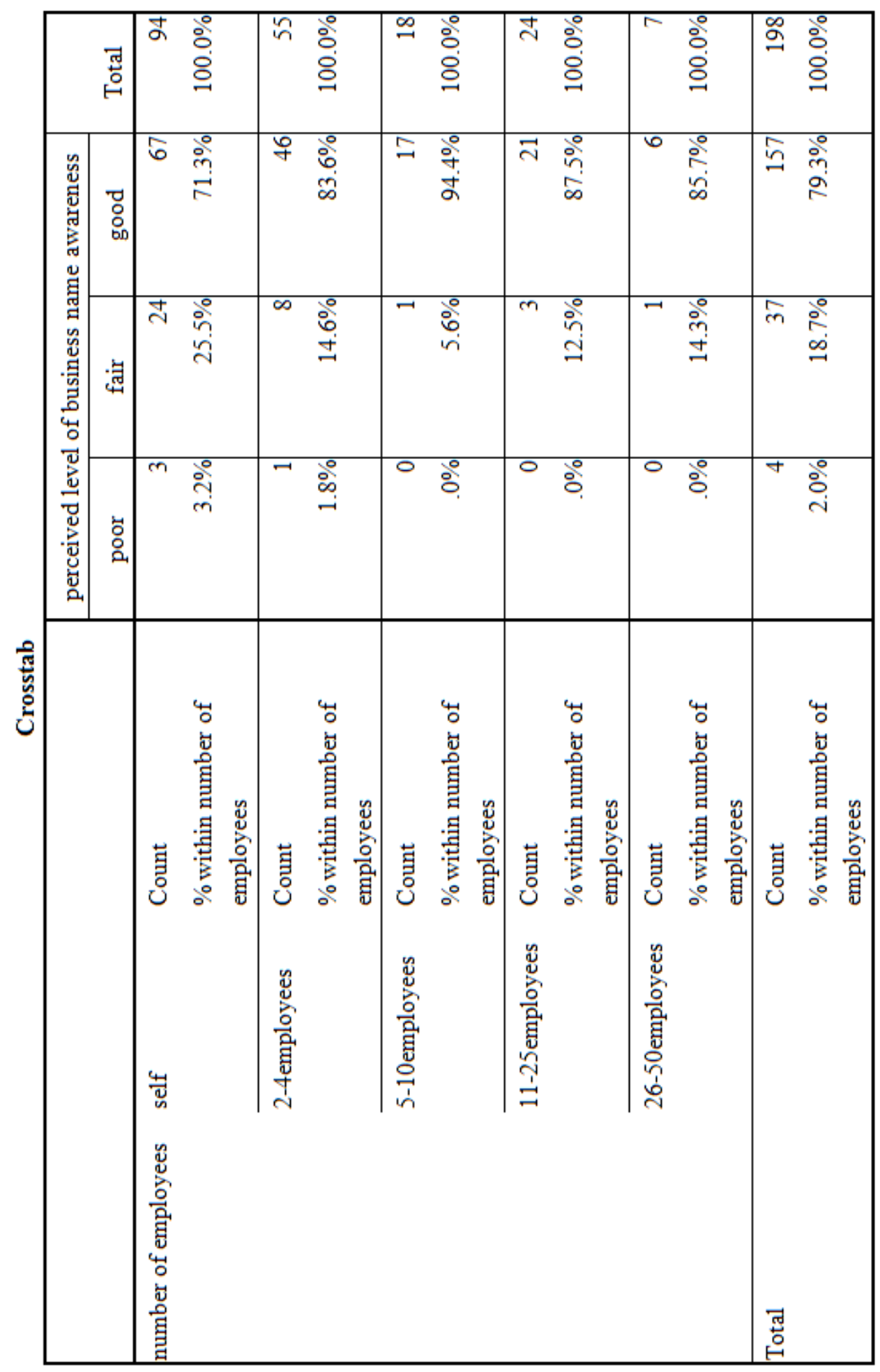




\section{Chi-Square Tests}

\begin{tabular}{|l|l|l|l|}
\hline & Value & $\mathrm{df}$ & $\begin{array}{l}\text { Asymp. Sig. } \\
(2 \text {-sided })\end{array}$ \\
\hline Pearson Chi-Square & $5.809^{\mathrm{a}}$ & 8 & .669 \\
Likelihood Ratio & 6.780 & 8 & .561 \\
Linear-by-Linear & 3.654 & 1 & .056 \\
Association & 198 & & \\
\hline
\end{tabular}

a. 9 cells $(60.0 \%)$ have expected count less than 5. The minimum expected count is .10 . 
Table IX: number of employees * level of customer retain

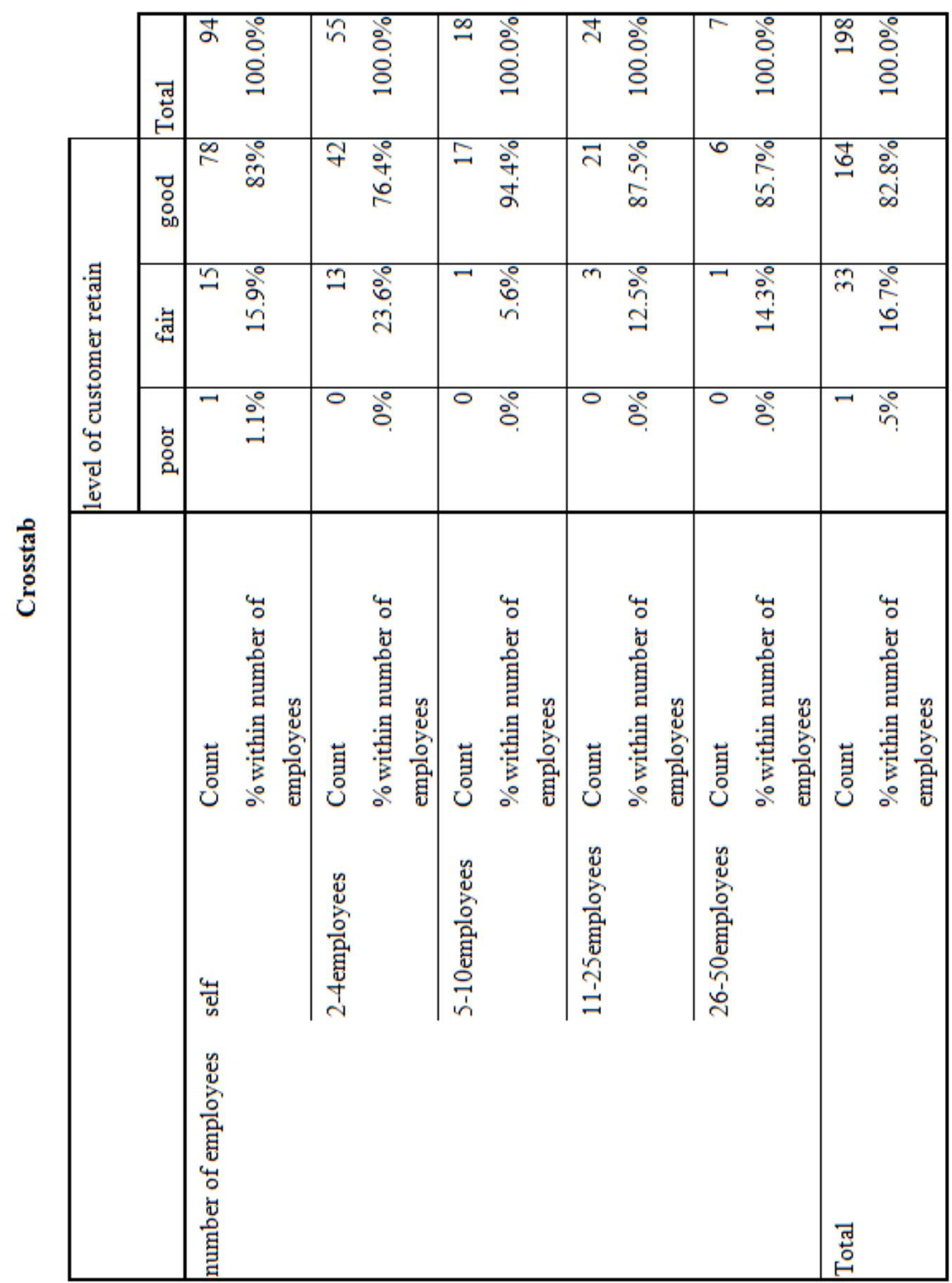

